\title{
THEORY OF PLANNED BEHAVIOR DAN READINESS FOR CHANGE DALAM MEMPREDIKSI NIAT IMPLEMENTASI PERATURAN PEMERINTAH NOMOR 71 TAHUN 2010
}

\author{
Nadhira Afdalia \\ Fakultas Ekonomi dan Bisnis Universitas Hasanuddin \\ e-mail: nadhira.afdalia@yahoo.com \\ Grace T.Pontoh \\ Fakultas Ekonomi dan Bisnis Universitas Hasanuddin \\ e-mail: gracetpontoh@gmail.com \\ Kartini \\ Fakultas Ekonomi dan Bisnis Universitas Hasanuddin \\ e-mail: hanafikartini@ rocketmail.com
}

\begin{abstract}
Theory of Planned Behavior (TPB) has been widely applied in various fields of behavioral research, to address behaviors that are not under the full control of the individual. This research aimed to analyzing the effect of: 1) attitude toward the behavior; 2) subjective norm; 3) perceived behavioral control; and 4) readiness for changeon the intention to implementing the Government Regulation No.71 Year 2010 concerning the accrual-based governmental accountingstandard. This research used a quantitative approach with the closed questionnaire method. The research samples were all heads of the offices and fields of the office of the Revenueof Regional Finance and Asset Management of the cities and regencies in Central Sulawesi. The research results indicates that the variables of the attitude toward behavior, subjective norm, and readiness for change have the positive and significanc effect on the intention, where as the perceived behavioral control variable does not indicate the significant relationship with theintention.
\end{abstract}

Keywords: Theory of planned behavior, readiness for change, intention.

\begin{abstract}
Abstrak
Theory of Planned Behavior (TPB) telah digunakan dalam penelitian tentang keperilakuan untuk menunjukkan bahwa perilaku tidak sepenuhnya di bawah pengaruh dari individu. Penelitian ini bertujuan untuk menganalisis pengaruh (1) sikap terhadap perilaku, (2) norma subjektif, (3) kontrol perilaku persepsian, dan (4) kesiapan untuk berubah terhadap niat untuk mengimplementasikan Peraturan Pemerintah No. 71 Tahun 2010 tentang Standar Akuntasi Pemerintahan Berbasis Akrual. Penelitian ini menggunakan metode kuantitatif dengan menyebarkan kuesioner. Sampel penelitian ini adalah kepala dinas dan kepala bidang di Dinas Pendapatan Pengelolaan Keuangan dan Aset Daerah Kota dan Kabupaten seluruh Sulawesi Tengah. Hasil penelitian ini mengindikasikan bahwa attitude toward behavior, subjective norms, dan readiness for change mempunyai pengaruh positif dan signifikan terhadap niat, sementara itu perceived behavioral control tidak mengindikasikan pengaruh yang signifikan terhadap niat.
\end{abstract}

Kata kunci: Theory of planned behavior, readiness for change, niat.

\section{PENDAHULUAN}

Theory of Planned Behavior (TPB) merupakan salah satu teori yang telah banyak diterap- kan diberbagai bidang penelitian perilaku. TPB menyatakan bahwa kombinasi dari sikap terhadap perilaku, norma subyektif, dan kon- 
trol perilaku persepsian mengarah pada pembentukan niat perilaku (behavioral intention) dan selanjutnya membentuk perilaku (behavior) (Jogiyanto, 2008). Implementasi Peraturan Pemerintah Nomor 71 tahun 2010 tentang Standar Akuntansi Pemerintahan Berbasis Akrual merupakan perilaku yang bersifat wajib (mandatory behavior). Menurut Hartwick dan Barki (1994) meskipun suatu perilaku bersifat wajib, namun dalam penerapannya dapat bervariasi. Hal ini berarti aparatur dapat memilih mengimplementasikan atau tidak mengimplementasikan PP Nomor 71 tahun 2010 dengan alasan atau pertimbangan tertentu.

Data hasil pemeriksaan badan pemeriksa keuangan (BPK) RI perwakilan Provinsi Sulawesi Tengah pada 12 pemerintah daerah Provinsi/Kabupaten/Kota se-Sulawesi Tengah menunjukkan bahwa masalah penatausahaan dan pengelolaan aset tetap, persediaan, serta kewajiban perpajakan merupakan masalah utama yang dihadapi hampir semua pemda di Sulawesi Tengah (BPK RI Sulawesi Tengah 2014). Diharapkan melalui penerapan PP Nomor 71 tahun 2010 yang wajib diimplementasikan pada tahun 2015 masalah-masalah tersebut dapat diatasi.

Penelitian yang terkait perilaku mandatory sebagian besar dilakukan pada bidang perpajakan. Penelitian yang dilakukan oleh Mustikasari (2007) dengan menggunakan model TPB, menjelaskan bahwa perilaku tidak patuh (noncompliance) wajib pajak sangat dipengaruhi oleh variabel sikap, norma subyektif, dan control perilaku yang dipersepsikan. Penelitian yang dilakukan oleh Pangestu dan Rusmana (2012) menunjukkan bahwa sikap dan kontrol perilaku berpengaruh signifikan terhadap niat, sedangkan norma subjektif tidak berpengaruh terhadap niat untuk berperilaku patuh. Penelitian oleh Taylor dan Todd (1995) membuktikan bahwa model TPB memberikan pemahaman yang lebih lengkap dalam menjelaskan tentang niat perilaku dan penggunaan.

Berbeda dengan penelitian-penelitian TPB sebelumnya, penelitian ini terkait dengan perilaku mandatory di bidang pengimplemen- tasian regulasi, yaitu peraturan pemerintah Nomor 71 Tahun 2010 tentang Standar Akuntansi Pemerintah Berbasis Akrual. Penelitian ini juga menambahkan variabel readiness for change, dengan pertimbangan bahwa kesiapan kolektif perilaku individu dalam organisasi merupakan faktor penting untuk mendukung perubahan organisasi. Ajzen (1991) juga menyatakan bahwa model TPB masih memungkinkan untuk ditambahkan variabel prediktor lain selain variabel pembentuk niat. Berdasarkan pemikiran mengenai pentingnya niat dalam berperilaku dan pentingnya kesiapan untuk berubah sebagai faktor penting dalam keberhasilan perubahan suatu organisasi, maka penelitian ini bertujuan untuk menganalisis pengaruh 1) sikap terhadap perilaku (attitude toward behavior); 2) norma subyektif (subjective norm); 3) kontrol perilaku persepsian (perceived behavior control); dan 4) kesiapan untuk berubah (readiness for change) terhadap niat (intention) mengimple mentasikan Peraturan Pemerintah Nomor 71 Tahun 2010 mengenai standar akuntasi pemerintahan berbasis akrual dengan menggunakan Theory of Planned Behavior (TPB) dan Readiness for Change sebagai landasan teori.

\section{TINJAUAN PUSTAKA DAN PERUMUSAN HIPOTESIS}

\section{Peraturan Pemerintah Nomor 71 Tahun 2010 tentang Standar Akuntansi Pemerin- tahan (SAP) Berbasis Akrual}

Akuntansi berbasis akrual adalah suatu basis akuntansi di mana transaksi ekonomi dan peristiwa lainnya diakui, dicatat, dan disajikan dalam laporan keuangan pada saat terjadinya transaksi tersebut, tanpa memperhatikan waktu kas atau setara kas diterima atau dibayarkan. Waktu pencatatan (recording) dalam akuntansi berbasis akrual, sesuai dengan saat terjadinya arus sumber daya sehingga dapat menyediakan informasi yang paling komprehensif karena seluruh arus sumber daya dicatat. Komponen laporan keuangan berdasarkan PP No. 71 tahun 2010, terdiri dari (a) laporan realisasi anggaran (LRA), (b) laporan perubahan saldo anggaran lebih (laporan perubahan (SAL), (c) neraca, (d) 
laporan operasional (LO), (e) laporan arus kas (LAK), (f) laporan perubahan ekuitas (LPE), dan $(\mathrm{g})$ catatan atas laporan keuangan.

Perbedaan kongkrit yang paling memerlukan perhatian adalah jenis/komponen laporan keuangan. Perbedaan mendasar SAP PP 24/2005 dengan SAP Akrual terletak pada PSAP 12 mengenai Laporan Operasional. Entitas pemerintah melaporkan secara transparan besarnya sumber daya ekonomi yang didapatkan dan besarnya beban yang ditanggung untuk menjalankan kegiatan pemerintahan. Surplus/defisit operasional merupakan penambah atau pengurang ekuitas/kekayaan bersih entitas pemerintahan bersangkutan.

Walaupun pertanggungjawaban pelaksanaan anggaran berbasis akrual berlaku efektif mulai tahun 2010 untuk laporan keuangan, tetapi apabila entitas pelaporan belum dapat menerapkan PSAP ini entitas pelaporan dapat menerapkan PSAP berbasis kas menuju akrual palig lama 4 (empat) tahun setelah tahun anggaran 2010. Penerapan SAP berbasis akrual dapat dilaksanakan secara bertahap dari penerapan SAP berbasis kas menuju akrual menjadi penerapan SAP berbasis akrual. Ketentuan lebih lanjut mengenai penerapan SAP berbasis akrual secara bertahap pada pemerintah pusat diatur dengan Peraturan Menteri Keuangan, sedangkan untuk pada pemerintah daerah diatur dengan Peraturan Menteri Dalam Negeri Pasal 7 Peraturan Pemerintah No. 71 Tahun 2010.

\section{Theory of Planned Behaviour (TPB)}

TPB merupakan pengembangan lebih lanjut dari Theory of Reasoned Action (TRA) atau teori tindakan beralasan (Ajzen 1991). TPB yang menjelaskan bahwa tindakan manusia diarahkan oleh tiga macam kepercayaan, yaitu (a) kepercayaan perilaku (behavioral beliefs), yaitu kepercayaan tentang kemungkinan terjadinya perilaku, (b) kepercayaan normatif (normative beliefs), yaitu kepercayaan tentang ekspektasi normatif dari orang lain dan motivasi untuk menyetujui ekspektasi tersebut, (c) kepercayaan kontrol (control beliefs), yaitu kepercayaan tentang keberadaan faktor-faktor yang akan memfasilitasi atau merintangi kinerja dari perilaku dan kekuatan persepsian dari faktor-faktor tersebut.

Secara keseluruhan, kepercayaankepercayaan perilaku membentuk suatu sikap menyukai atau tidak menyukai terhadap perilaku, kepercayaan normatif menghasilkan tekanan sosial atau norma subyektif, dan kepercayaan kontrol akan memberikan kontrol perilaku persepsian. Bersama-sama, sikap terhadap perilaku, norma subyektif, dan kontrol perilaku persepsian, akan menimbulkan niat perilaku (behavioral intention) dan selanjutnya terbentuk perilaku (behavior).

\section{Sikap (Attitude)}

Fishbein dan Ajzen (1975) mendefinisikan sikap sebagai jumlah dari efeksi (perasaan) yang dirasakan seseorang untuk menerima atau menolak suatu obyek atau perilaku dan diukur dengan suatu prosedur yang menempatkan individual pada skala evaluative dua kutub, misalnya baik atau jelek, setuju atau menolak. Sikap menurut Ajzen (2002) merupakan suatu keadaan internal (internal state) yang memengaruhi pilihan tindakan individu terhadap objek, orang atau kejadian tertentu. Sikap merupakan kecenderungan kognitif, afektif, dan tingkah laku yang dipelajari untuk berespon secara positif maupun negatif terhadap objek, situasi, institusi, konsep atau seseorang.

Berdasarkan teori ini, sikap individu terhadap suatu perilaku diperoleh dari keyakinan terhadap konsekuensi yang ditimbulkan oleh perilaku tersebut, yang diistilahkan dengan behavioral beliefs (keyakinan terhadap perilaku). Keyakinan terhadap perilaku menghubungkan perilaku dengan hasil tertentu, atau beberapa atribut lainnya seperti biaya atau kerugian yang terjadi saat melakukan suatu perilaku. Dengan kata lain, seseorang yang yakin bahwa sebuah tingkah laku dapat menghasilkan outcome yang positif, maka individu tersebut akan memiliki sikap yang positif, begitu juga sebaliknya.

\section{Norma Subyektif (Subjective Norm)}

Norma-norma subyektif adalah persepsi atau pandangan seseorang terhadap kepercayaan- 
kepercayaan orang lain yang akan memengaruhi niat untuk melakukan atau tidak melakukan perilaku yang sedang dipertimbangkan (Jogiyanto 2008). Norma subyektif menggambarkan sejauh mana seseorang memiliki motivasi untuk mengikuti pandangan orang terhadap perilaku yang akan dilakukannya (normative belief) jika individu merasa itu adalah hak pribadinya untuk menentukan apa yang akan dia lakukan bukan ditentukan oleh orang lain di sekitarnya, maka dia akan mengabaikan pandangan orang tentang perilaku yang akan dilakukannya. Fishbein dan Ajzen (1975) menggunakan istilah "motivation to comply" untuk menggambarkan fenomena ini yaitu apakah individu mematuhi pandangan orang lain yang berpengaruh dalam hidupnya atau tidak.

Keyakinan normatif berkenaan dengan harapan-harapan yang berasal dari referent atau orang dan kelompok yang berpengaruh bagi individu (significant others) seperti orang tua, pasangan, teman dekat, rekan kerja atau lainnya, tergantung pada perilaku yang terlibat (Ajzen 2005). Norma Subjektif didefinisikan sebagai adanya persepsi individu terhadap tekanan sosial yang ada untuk menunjukkan atau tidak suatu perilaku. Individu memiliki keyakinan bahwa individu atau kelompok tertentu akan menerima atau tidak menerima tindakan yang dilakukannya. Apabila individu meyakini apa yang menjadi norma kelompok, maka individu akan mematuhi dan membentuk perilaku yang sesuai dengan kelompoknya.

\section{Kontrol Perilaku Persepsian (Perceived Behavior Control)}

Schifter dan Ajzen (1985) menambahkan sebuah konstruk yang sebelumnya tidak ada di dalam TRA. Konstruk ini ditambahkan ke TPB untuk mengontrol perilaku yang dibatasi oleh keterbatasan-keterbatasan kurangnya sumber daya untuk melakukan perilaku. Konstruk yang ditambahkan tersebut adalah kontrol perilaku persepsian (perceived behavioral control). Kontrol perilaku persepsian didefinisikan sebagai kemudahan atau kesulitan persepsian untuk melakukan perilaku (Ajzen
1991). Ajzen (2005) menamakan kondisi ini dengan kontrol perilaku persepsian.

Banyak faktor yang dapat mengganggu hubungan antara niat dan perilaku. Keberhasilan kinerja dan perilaku tergantung dari kemampuan seseorang untuk mengontrol faktor-faktor yang dapat mempengaruhi perilaku, walaupun kontrol kemauan (volitional control) adalah salah satu yang paling memengaruhi perilaku dibandingkan dengan faktor-faktor yang lain, keterbatasan-keterbatasan personal dan hambatan-hambatan eksternal dapat juga mengganggu kinerja dari perilaku (Ajzen 1991). Ajzen (1991) mencoba menyediakan suatu kerangka konseptual untuk membahas permasalahan dari kontrol volitional yang kurang lengkap dengan menambahkan sebuah konstruk yaitu kontrol perilaku persepsian.

Perlu diperhatikan bahwa TPB tidak secara langsung berhubungan dengan jumlah dari kontrol yang sebenarnya dimiliki seseorang, tetapi teori ini lebih mempertimbangkan pengaruh-pengaruh yang mungkin dari kontrol perilaku yang dipersepsikan dalam pencapaian tujuan-tujuan perilaku. Jika niat menunjukan keinginan seseorang untuk mencoba perilaku tertentu, kontrol persepsian lebih kepada mempertimbangkan beberapa konstrain-konstrain yang realistik yang mungkin terjadi.

\section{Kesiapan Untuk Berubah (Readiness for Change)}

Kesiapan untuk berubah merupakan suatu sikap yang komprehensif yang dipengaruhi secara simultan oleh empat faktor, yaitu apa yang berubah (the content), bagaimana perubahan tersebut dilakukan (the process), keadaan di mana perubahan tersebut akan berlangsung (the context), dan karakteristik dari orang yang diminta untuk melakukanya (the individuals). Keempat faktor tersebut secara bersama-sama terefleksi ke dalam ingatan seseorang atau sekelompok orang secara kognitif dan emosional untuk cenderung menerima, menganut, dan mengadopsi perubahan yang dipersiapkan dan direncanakan untuk mengganti keadaan saat ini (Holt et al., 2007). 
Kesiapan individu dalam organisasi untuk berubah akan menunjukkan kesiapan organisasi.

Teori Holt menjelaskan bahwa kesiapan untuk berubah menyediakan fondasi atas resistensi dari perilaku yang diadaptasi oleh perubahan. Menurut Walinga (2008) disebutkan bahwa teori kesiapan untuk berubah diyakini sebagai perubahan kognisi dari tiap individu. Menurut Holt, et al. (2007) kesiapan (readiness) merupakan faktor yang paling penting dalam mendukung inisiatif individu untuk melakukan perubahan. Kesiapan didefinisikan sebagai keyakinan, intensi, sikap dan perilaku yang mendukung perubahan dan kapasitas organisasi untuk sukses meraihnya. Kesiapan untuk berubah merupakan suatu konstruk multi dimensional yang terdiri dari empat dimensi, yaitu kesesuaian (apropriateness), kepercayaan diri untuk berubah (change efficacy), dukungan manajemen (management support), dan keuntungan bagi diri (personal valence).

Menerapkan perubahan organisasi yang kompleks melibatkan tindakan dari banyak individu, setiap individu memberikan suatu konstribusi sebagai upaya implementasi. Hal ini dikarenakan implementasi seringkali merupakan kerjasama tim, masalah dapat muncul ketika beberapa individu merasa berkomitmen untuk melaksanakan implementasi tetapi yang lainnya tidak. Weiner (2009) mengamati bahwa anggota organisasi dapat berkomitmen untuk menerapkan perubahan organisasi karena mereka ingin (mereka menghargai perubahan), karena mereka harus (mereka memiliki sedikit pilihan), atau karena mereka seharusnya (mereka merasa wajib). Komitmen yang berdasarkan motif 'keinginan untuk' mencerminkan komitmen tertinggi untuk menerapkan perubahan organisasi.

Secara khusus, kesiapan organisasi untuk berubah mengacu kepada komitmen dan keyakinan-sendiri dari semua anggota organisasi untuk mengimplementasikan perubahan organisasi. Pengertian ini mengandung kata 'kesiapan' yang berarti kondisi yang tepat secara psikologis maupun perilaku untuk mengambil suatu tindakan. Mengacu pada definisi yang dikemukakan oleh Bandura
(1977) dalam teori kognitif sosial mengenai komitmen tujuan, yaitu komitmen perubahan yang mengacu pada keyakinan-bersama dari anggota organisasi untuk melakukan tindakan dalam implementasi perubahan (Weiner 2009).

\section{Niat (Intention)}

Niat (intention) didefinisikan sebagai keinginan untuk melakukan perilaku. Niat tidak selalu statis, niat dapat berubah seiring berjalannya waktu. Semakin lebar interval waktu, semakin mungkin terjadi perubahan-perubahan pada niat (Jogiyanto 2008). TPB mengatakan bahwa seseorang dapat bertindak berdasarkan intensi atau niatnya hanya jika ia memiliki kontrol terhadap perilakunya (Ajzen 2002).

Niat merupakan suatu fungsi dari dua penentu dasar, penentu yang pertama berhubungan dengan faktor pribadi adalah sikap terhadap perilaku dan penentu yang kedua dari niat yang berhubungan dengan pengaruh sosial adalah norma subjektif. TPB menjelaskan bahwa seseorang dapat bertindak berdasarkan intensi atau niatnya jika ia memiliki kontrol terhadap perilakunya (Ajzen 2002), kontrol perilaku persepsian mempunyai implikasi motivasional terhadap niat-niat.

\section{Pengaruh Sikap Terhadap Niat}

Penentu niat yang berhubungan dengan faktor pribadi adalah sikap terhadap perilaku individual (Jogianto 2008). Sikap adalah perasaan positif atau negatif dari seseorang jika harus melakukan perilaku yang akan ditentukan (Jogiyanto 2008). Sikap aparatur mengenai implementasi Peraturan Pemerintah Nomor 71 akan menimbulkan motivasi untuk mengimplementasikan Peraturan Pemerintah Nomor 71 tahun 2010, sehingga akan mendorong niat untuk mengimplementasikan Peraturan Pemerintah Nomor 71 tahun 2010 secara optimal dan sesuai peraturan.

Penelitian yang dilakukan oleh Ozer dan Yilmaz (2011) menunjukkan bahwa sikap memiliki kemampuan prediksi lebih daripada norma subyektif dan kontrol perilaku persepsian. Pangestu dan Rusmana (2012), Mustika- 
sari (2011), Hidayat dan Nugroho (2010), Smart (2012) serta Bidin et al. (2011) meneliti di bidang perpajakan telah membuktikan secara empiris bahwa sikap berpengaruh positif terhadap niat. Semakin positif sikap wajib pajak untuk patuh terhadap pajak maka niat wajib pajak untuk patuh akan semakin besar (Pangestu dan Rusmana 2012), sedangkan penelitian yang dilakukan Mustikasari (2007) menunjukkan bahwa apabila sikap ketidakpatuhan pajak positif, maka niat untuk tidak patuh pajak juga akan tinggi. Berdasarkan penjelasan dan hasil penelitian tersebut dirumuskan hipotesis sebagai berikut.

H1: Sikap terhadap Peraturan Pemerintah nomor 71 berpengaruh positif dan signifikan terhadap niat untuk mengimplementasikan Peraturan Pemerintah Nomor 71 tahun 2010 tentang standar akuntansi pemerintahan berbasis akrual.

\section{Pengaruh Norma Subyektif Terhadap Niat}

Niat juga ditentukan oleh pengaruh sosial yaitu norma subyektif Jogiyanto (2008). Variabel kedua dari model TPB ini didefinisikan sebagai persepsi atau pandangan seseorang terhadap kepercayaan-kepercayaan orang lain yang akan mempengaruhi niat untuk melakukan atau tidak melakukan perilaku yang sedang dipertimbangkan Jogiyanto (2008). Beberapa penelitian menunjukkan bahwa norma subyektif berpengaruh positif terhadap niat seperti Bidin et al. (2011) serta Hidayat dan Nugroho (2010) di bidang perpajakan, penelitian yang dilakukan oleh Sihombing (2004) menunjukkan bahwa norma subjektif merupakan faktor penentu niat terbaik di negara timur. Taylor dan Todd (1995) mengatakan bahwa norma subyektif adalah pediktor niat yang penting baik pada pengguna yang memiliki pengalaman sebelumnya atau tidak.

Hasil penelitian yang dilakukan oleh Mustikasari (2007) di bidang perpajakan menunjukkan bahwa pengaruh orang sekitar (perceived social pressure) yang kuat akan memengaruhi niat tax professional untuk berperilaku patuh. Penelitian yang dilakukan oleh Ajzen dan Fishbein (1970) menyatakan bahwa dalam situasi orientasi cooperative norma subjektif memiliki pengaruh yang tinggi terhadap niat dibandingkan dengan ketika diterapkan dalam situasi orientasi motivasi yang kompetitif. Implementasi Peraturan Pemerintah merupakan situasi yang berorientasi pada motivasi cooperative. Berdasarkan penjelasan dan hasil penelitian tersebut dirumuskan hipotesis sebagai berikut.

$\mathrm{H} 2$ : Norma subyektif berpengaruh positif dan signifikan terhadap niat untuk mengimplementasikan Peraturan Pemerintah Nomor 71 tahun 2010 tentang standar akuntansi pemerintahan berbasis akrual.

\section{Pengaruh Kontrol Perilaku Persepsian Terhadap Niat}

Ajzen (1991) mengatakan bahwa kontrol perilaku yang dipersepsikan memengaruhi niat didasarkan atas asumsi bahwa kontrol perilaku yang dipersepsikan oleh individu akan memberikan implikasi motivasi pada orang tersebut. Kontrol perilaku persepsian ditentukan oleh adanya control beliefs yaitu kepercayaan tentang keberadaan faktor-faktor yang akan memfasilitasi atau justru menghalangi perilaku (Jogiyanto 2008). Jika individu merasa dirinya memiliki kualifikasi dan kemampuan yang dibutuhkan untuk mengimplementasikan basis akrual secara penuh sesuai dengan peraturan pemerintah nomor 71 Tahun 2010, maka kemungkinan niatnya untuk mengimplementasikan basis akrual secara penuh sesuai dengan peraturan pemerintah nomor 71 tahun 2010 akan semakin tinggi dan pada akhirnya akan memilih untuk mengimplementasikannya secara optimal dan menghasilkan kinerja terbaik.

Penelitian yang dilakukan oleh Huda et al. (2012) menunjukkan pengaruh yang signifikan antara kontrol perilaku persepsian dan niat. Hal serupa juga ditunjukkan oleh penelitian Pangestu dan Rusmanan (2012) di bidang perpajakan, kontrol perilaku persepsian berpengaruh positif dan signifikan terhadap niat. Hal ini menunjukkan bahwa semakin tinggi persepsi wajib pajak atas kendali dan kesanggupan yang dimilikinya akan mendorong niat wajib pajak untuk patuh. Sesuai dengan teori planned behavior oleh Ajzen \& 
Fishbein (1970), factor persepsi pengendalian perilaku memiliki karakteristik untuk memperkuat dan melemahkan niat. Jika perilaku yang dianggap bisa dilakukan, niat akan diperkuat. Jika perilaku dianggap sulit atau tidak mungkin untuk dilakukan, niat melemah. Berdasarkan penjelasan dan hasil penelitian tersebut dirumuskan hipotesis sebagai berikut.

H3: Kontrol perilaku persepsian berpengaruh positif dan signifikan terhadap niat untuk mengimplementasikan Peraturan Pemerintah Nomor 71 tahun 2010 tentang standar akuntansi pemerintahan berbasis akrual.

\section{Pengaruh Kesiapan untuk Berubah Ter- hadap Niat}

Implementasi sistem akuntansi berbasis akrual pada pemerintah daerah merupakan bentuk perubahan. Kesiapan organisasi untuk berubah mengacu kepada komitmen dan keyakinansendiri dari semua anggota organisasi untuk mengimplementasikan perubahan organisasi. Disamping itu dibutuhkan sumber daya aparatur yang siap untuk menghadapi perubahan sehingga efektifitas implementasi dapat terlaksana dengan baik. Penelitian Eby et al. (2010) menunjukkan bahwa individu-individu yang percaya diri mereka mampu berdaptasi dengan mudah terhadap perubahan cenderung akan memandang perubahan yang terjadi dalam organisasi akan sangat menguntungkan sehingga akan mendukung implementasi per- ubahan yang tentunya akan memengaruhi niat mereka untuk mengimplementasikan perubahan. Penelitian Nugraheni (2012) yang mendukung penelitian Eby et al. (2010) mengatakan kesiapan untuk berubah akan memengaruhi pola pikir, perasaan, dan perhatian individu yang tercermin dalam perilaku yang berawal dari niatnya. Penelitian yang dilakukan Kwahk dan Lee (2008) secara khusus menemukan bahwa readiness for change memiliki efek tidak langsung pada niat perilaku untuk menggunakan sistem Enterprise Resource Planning (ERP). Berdasarkan penjelasan dan hasil penelitian tersebut dirumuskan hipotesis sebagai berikut.

H4: Kesiapan untuk berubah berpengaruh positif dan signifikan terhadap niat untuk mengimplementasikan Peraturan Pemerintah Nomor 71 tahun 2010 tentang standar akuntansi pemerintahan berbasis akrual.

\section{METODA PENELITIAN}

\section{Jenis Penelitian, Lokasi, Waktu, dan Sampel Penelitian}

Penelitian ini merupakan penelitian kuantitatif yang bertujuan untuk mengetahui pengaruh variabel sikap, norma subyektif, kesiapan untuk berubah, dan kontrol perilakupersepsian terhadap niat implementasi PP Nomor 71 tahun 2010. Model penelitian yang menunjukkan hubungan antara variabel penelitian dapat dilihat pada gambar 1 .

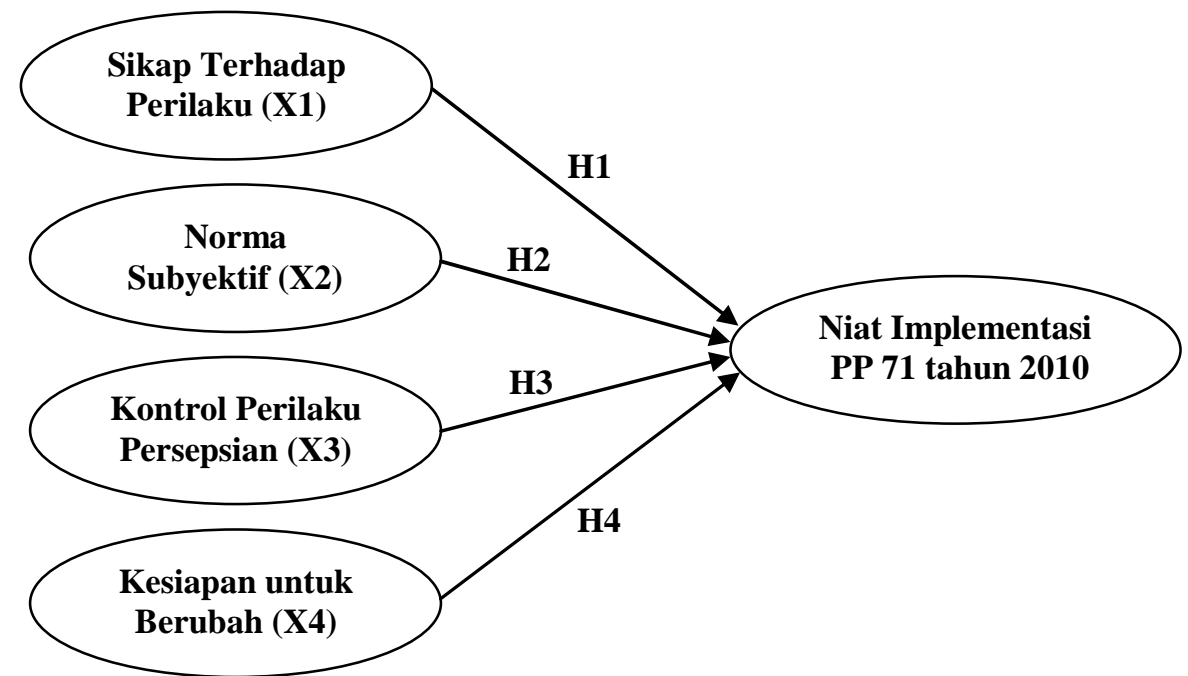

Gambar 1: Model Penelitian 
Penelitian ini dilakukan di Kota dan Kabupaten se-Sulawesi Tengah Desember 2013 sampai Februari 2014. Populasi dalam penelitian ini, yaitu seluruh kepala dinas dan kepala bidang dinas pendapatan pengelolaan keuangan dan aset daerah (DPPKAD) Kota dan Kabupaten se-Sulawesi Tengah yang berjumlah 56 responden. Seluruh anggota populasi dijadikan sampel penelitian dengan pertimbangan bahwa pejabat DPPKAD memiliki pemahaman yang lebih baik mengenai PP Nomor 71 tahun 2010.

\section{Jenis Data dan Teknik Pengumpulan Data}

Jenis data dalam penelitian ini adalah data subyek (self-report data). Teknik pengumpulan data menggunakan kuesioner dengan skala likert 5 poin, dari kategori sangat tidak setuju sampai kategori sangat setuju dengan jenis skala ordinal. Sebelum kuesioner digunakan, terlebih dahulu dilakukan uji pilot terhadap 33 orang mahasiswa kelas magister akuntansi di UNHAS untuk mengetahui validitas indikator variabel penelitian.

\section{Teknik Analisis Data}

Teknik analisis data menggunakan analisis statistik Partial Least Square (PLS) untuk mengetahui hubungan antar variabel yang diteliti. Analisis data menggunakan PLS terdiri dari dua sub model yaitu model pengukuran (outer model) untuk menilai validitas konstruk dan reliabilitas instrumen, dan model struktural (inner model) untuk menguji hipo- tesisone-tailed, dengan skor atau nilai $\mathrm{T}$ statistik harus lebih besar darinilai T-Tabel $(1,64)$ pada taraf alpha 5 persen. Validitas konstruk dapat diukur dengan parameter skor loading di model penelitian (rule of thumbs $>$ 0,7) dan menggunakan parameter AVE, communality, $\mathrm{R}^{2}$, dan redudancy. Skor AVE harus $>0,5$, Communality $>0,5$, dan redudancy mendekati 1. Jika skor loading <0,5 maka indikator ini dapat dihapus dari konstruknya. Jika skor loading antara 0,5-0,7 sebaiknya indikator yang memiliki skor loading tersebut tidak dihapus sepanjang skor AVE dan communality indikator tersebut $>0,5$. Uji validitas konvergen diukur dengan melihat skor AVE dan communality yang masingmasing harus bernilai diatas 0,5 . Uji Validitas diskriminan paramenter yang diukur adalah dengan membandingkan akar dari AVE suatu kontruk harus lebih tinggi dibandingkan dengan korelasi antar variabel laten tersebut, atau dengan melihat skor cross loading. Uji reliabilitas dapat dilihat dari nilai cronbach's alpha harus >0,6 dan nilai composite reliability harus $>0,7$ (Jogiyanto dan Abdillah 2009: 81).

\section{HASIL DAN PEMBAHASAN}

\section{Demografi Responden}

Kuesioner yang disebar kepada responden sebanyak 56, kuesioner yang kembali sebanyak 45 , kuesioner yang tidak lengkap 6 , dan kuesioner yang diolah sebanyak 39 . Data demografi responden dapat dilihat pada Tabel 1.

Tabel 1: Data Demografi Responden

\begin{tabular}{lcccl}
\hline & \multicolumn{3}{c}{ Data Demografi } \\
\cline { 2 - 5 } No & Umur & $\begin{array}{c}\text { Pendidikan } \\
\text { Terakhir }\end{array}$ & Jabatan & \multicolumn{1}{c}{$\begin{array}{c}\text { Lama Menduduki } \\
\text { Jabatan }\end{array}$} \\
\hline 1 & $30-35$ tahun $(20,51 \%)$ & S1(28,21\%) & Kepala dinas DPPKAD $(7,69 \%)$ & $<1$ tahun $(15,39 \%)$ \\
2 & $36-40$ tahun $(20,51 \%)$ & S2 (71,79\%) & Kepala Bidang $(92,31 \%)$ & $1-3$ tahun $(64,1 \%)$ \\
3 & $41-45$ tahun $(20,51 \%)$ & & & $4-6$ tahun $(17,95 \%)$ \\
4 & $46-50$ tahun $(7,69 \%)$ & & & $>6$ tahun $(2,56 \%)$ \\
5 & $51-55$ tahun $(23,07 \%)$ & & & \\
6 & $>56$ tahun $(7,69 \%)$ & & & \\
\hline Sumber: Data diolah, 2013 & & &
\end{tabular}




\section{Hasil Uji Validitas Konstruk, Validitas Konvergen, dan Validitas Diskriminan}

Hasil uji validitas konstruk dengan menggunakan software Smart PLS ver. 2.0 M3, menunjukkan bahwa indikator AT1, PBC1, PBC2, PBC3, PBC4, RC1, dan RC2 kurang valid, karena nilai loading factor kurang dari 0,70. Analisis selanjutnya indikator AT1, PBC2, PBC3, PBC4, RC1, dan RC2 masih tetap digunakan karena nilai AVE dan Communality $>0,5$. PBC1 tidak diikutkan karena meitiki nilai loading factor kurang dari 0,7 pada konstruknya dan nilai AVE dan Communality $<0,5$. Setelah diadakan revisi pengujian outer model, didapatkan hasil seluruh item pernyataan telah valid, yaitu loading factor $>$ 0,5, AVE >0,5 dan Communality >0,5 serta Redudancy mendekati 1 .

Hasil uji validitas konvergen menunjukkan bahwa semua AVE dan Communality memiliki nilai di atas 0,5 , yang berarti bahwa indikator-indikator konstruk memenuhi syarat validitas konvergen. Hasil uji validitas diskriminan pada Tabel 2 menunjukkan bahwa indikator yang digunakan dalam penelitian ini telah memenuhi kriteria validitas diskriminan karena nilai akar AVE semuanya lebih besar dari korelasi variabel laten.

\section{Hasil Uji Reliabilitas}

Hasil uji reliabilitas dengan menggunakan Cronbach'alpha dan composite reliability pada Tabel 3 menunjukkan nilai cronbach's alpha dan composite reliability untuk masingmasing variabel di atas nilai 0,7 , namun variabel perceived behavior control memiliki nilai cronbach's alpha 0,638657, namun nilai composite reliability di atas 0,7 sehingga masih dapat diterima.

\section{Hasil Uji Model Struktural}

Hasil perhitungan SmartPLS menunjukkan hasil estimasi $R$-square intention to implementation peraturan pemerintah nomor 71 tahun 2010 adalah sebesar 0,335343, yang artinya bahwa 33,53\% variabel sikap (attitude), norma subyektif (subjective norm), kontrol perilaku persepsian (perceived behavior control), dan kesiapan untuk berubah (readiness for change)memengaruhi variabel intention to implementation, sedangkan sisanya sebesar $66,47 \%$ dipengaruhi oleh variabel lain di luar model penelitian ini. Artinya masih terdapat variabel lain diluar model yang berpengaruh terhadap variabel intention to implementation. Kemungkinan variabel lain yang berpengaruh penting terhadap niat implementasi regulasi adalah variabel dukungan organisasi (organization support).

Tabel 2: Average Variance Extracted (AVE) dan Akar AVE

\begin{tabular}{lcc}
\hline \multicolumn{1}{c}{ Variabel } & AVE & Akar AVE \\
\hline Attitute $(A T)$ & 0,614845 & 0,78412 \\
Subjective Norm $(S N)$ & 0,795208 & 0,89174 \\
Perceived Behavior Control $(P B C)$ & 0,574954 & 0,75825 \\
Readiness for Change $($ RC) & 0,636740 & 0,79795 \\
Intention (I) & 0,851433 & 0,92273 \\
\hline
\end{tabular}

Sumber: Data diolah, 2013

Tabel 3: Uji Reliabilitas Variabel.

\begin{tabular}{lccc}
\hline \multicolumn{1}{c}{ Variabel } & $\begin{array}{c}\text { Composite } \\
\text { Reliability }\end{array}$ & $\begin{array}{c}\text { Cronbachs } \\
\text { Alpha }\end{array}$ & Keterangan \\
\hline Attitute (AT) & 0,860334 & 0,815225 & Reliabel \\
Subjective Norm (SN) & 0,885196 & 0,772236 & Reliabel \\
Perceived Behavior Control $(P B C)$ & 0,801235 & 0,638657 & Reliabel \\
Readiness for Change (RC) & 0,895846 & 0,872168 & Reliabel \\
Intention (I) & 0,944715 & 0,911229 & Reliabel \\
\hline
\end{tabular}

Sumber: Data diolah, 2013 


\section{Hasil Uji Hipotesis}

Tabel 4: Hasil Uji Hipotesis (Path Coefficients)

\begin{tabular}{lccc}
\hline & Original Sample $(\boldsymbol{O})$ & T Statistics $(\mid \boldsymbol{O} /$ STERR $\mid)$ & Keterngan \\
\hline AT $\rightarrow$ I & 0,184800 & 1,715688 & Diterima \\
PBC $\rightarrow$ I & $-0,163645$ & 1,203452 & Ditolak \\
SN $\rightarrow$ I & 0,183547 & 1,671433 & Diterima \\
RC $\rightarrow$ I & 0,459393 & 3,561792 & Diterima \\
\hline
\end{tabular}

Sumber: Data diolah, 2013

Pada Tabel 4 dapat dilihat hasil uji hipotesis yang menunjukkan bahwa variabel sikap, norma subyektif, dan kesiapan untuk berubah seluruhnya memiliki nilai $\mathrm{t}$ statistik yang lebih besar dibandingkan dengan nilai t tabel 1,64 $(\alpha 0,05)$ dan nilai original sample bernilai positif. Hal ini berarti variabel sikap, norma subyektif, dan kesiapan untuk berubah berpengaruh positif dan signifikan terhadap niat untuk mengimplementasikan Peraturan Pemerintah Nomor 71 Tahun 2010. Variabel kontrol perilaku persepsian memiliki nilai t statistik yang lebih kecil dibandingkan dengan nilai t tabel 1,64 $(\alpha 0,05)$ dengan nilai original sample bernilai negatif. Hal ini berarti variabel kontrol perilaku persepsian tidak berpengaruh positif dan signifikan terhadap niat untuk mengimplementasikan Peraturan Pemerintah Nomor 71 Tahun 2010.

Sikap terhadap perilaku pada penelitian ini adalah perasaan negatif atau positif dari aparatur pemerintah daerah Kota dan Kabupaten se Sulawesi Tengah, terhadap nilai kebaikan, nilai kebijaksanaan, nilai kesukaan, dan nilai kesenangan dari implementasi peraturan pemerintah (PP) Nomor 71 Tahun 2010. Hasil penelitian menunjukkan bahwa sikap terhadap perilaku merupakan salah satu variabel penentu dari niat seseorang. Sejalan dengan pendapat Ajzen dan Fishbein (1970) yang menyatakan bahwa sikap terhadap perilaku dapat memprediksi niat perilaku seseorang. Data demografi menunjukkan $71,79 \%$ responden memiliki pendidikan $\mathrm{S} 2$ dan 92,31\% memiliki jabatan kepala bidang. Apabila dihubungkan dengan variabel sikap terhadap perilaku, tingkat pendidikan dan jabatan responden dapat memberikan pengetahuan dan pengalaman yang lebih banyak, yang akan menjadi dasar dalam melakukan evaluasi ter- hadap hasil dari implementasi PP Nomor 71 Tahun 2010. Menurut Ajzen (1991) kepercayaan-kepercayaan perilaku, ditentukan oleh evaluasi terhadap hasil yang dihubungkan dengan perilaku dan juga kekuatan-kekuatan dari asosiasi-asosiasi tersebut.

Aparatur pemerintah daerah kota dan kabupaten se Sulawesi Tengah yang percaya bahwa perilaku implementasi PP Nomor 71 Tahun 2010 akan mengarahkan terutama ke hasil-hasil positif, maka mereka akan mempertahankan sikap yang baik terhadap melakukan perilaku tersebut, dan sebaliknya aparatur pemerintah daerah yang percaya melakukan perilaku tersebut akan mengarahkan ke hasil-hasil negatif akan mempertahankan sikap yang kurang baik. Hasil penelitian ini mendukung penelitian sebelumnya yang dilakukan oleh Ozel dan Yilmaz (2011), Pangestu dan Rusmana (2012), Mustikasari (2011), Hidayat dan Nugroho (2010), Smart (2012), serta Bidin et al. (2011). Tiga variabel yang digunakan sebagai alat untuk memprediksi niat dalam theory of planned behavior, berdasarkan hasil penelitian ini sikap memiliki kemampuan prediksi yang lebih baik terhadap niat dibandingkan dengan dua variabel lainnya.

Jogiyanto (2008) menjelaskan bahwa norma subyektif (subjective norm) diasumsikan sebagai suatu fungsi kepercayaan-kepercayaan seseorang, bahwa individu-individu tertentu atau kelompok-kelompok menyetujui atau tidak menyetujui melakukan suatu perilaku. Apabila dihubungkan dengan hasil penelitian ini, aparatur pemerintah daerah kota dan kabupaten se Sulawesi Tengah memiliki norma subyektif yang kuat, yang dibentuk oleh kepercayaan-kepercayaan normatif mereka, bahwa implementasi PP Nomor 71 Tahun 
2010, akan mendapat dukungan dari atasan atau pimpinan, rekan kerja, ataupun bawahan mereka. Kepercayaan normatif tersebut, menjadi motivasi bagi aparatur pemerintah daerah untuk bertindak sesuai dengan harapan normatif mereka. Hal ini sesuai dengan yang dinyatakan oleh Ajzen (2005) bahwa apabila individu meyakini apa yang menjadi norma kelompok, maka ia akan mematuhi dan membentuk perilaku yang sesuai dengan kelompoknya. Jogiyanto (2008) memandang norma subyektif sebagai dua bentuk pengaruh, yaitu pengaruh interpersonal dan pengaruh eksternal. Dalam penelitian ini, pengukuran norma subyektif terkait dengan pengaruh interpersonal, yang berasal dari pimpinan dan rekan kerja.

Data demografi responden menunjukkan 58,8\% responden berusia diatas 40 tahun, $71,8 \%$ memiliki pendidikan S2, dan lama bekerja diatas 1 tahun sebanyak 84,6\%. Datadata tersebut merupakan bagian dari faktor sosial yang dapat membentuk norma subyekti. Semakin tua usia seseorang dan semakin lama ia bekerja, maka pengalaman hidup yang dipeolehnya akan semakin banyak. Begitu juga dengan tingkat pendidikan, semakin tinggi tingkat pendidikan seseorang, maka pengetahuan dan pengalaman yang diperolehnya juga semakin banyak. Ajzen (2005), menjelaskan bahwa beberapa faktor sosial yang dapat membentuk keyakinan normatif seseorang, yaitu; usia, jenis kelamin, pendidikan, pendapatan, pengalaman, dan pengetahuan. Keyakinan normatif akan membentuk norma subyektif yang akan mempengaruhi niat perilaku seseorang.

Kontrol perilaku persepsian (perceived behavioral control) berhubungan dengan persepsi manusia mengenai kemudahan atau kesulitan dalam melakukan suatu perilaku yang diinginkan (Ajzen 2005). Dalam penelitian ini, kontrol perilaku persepsian mengacu pada keputusan pribadi, sumber daya, pengetahuan, dan kemampuan individu untuk mengimplementasikan PP Nomor 71 Tahun 2010. Hasil penelitian ini membuktikan bahwa kontrol perilaku persepsian tidak berpengaruh positif dan signifikan terhadap niat untuk mengimplementasikan PP Nomor 71 Tahun 2010. Hasil penelitian ini sejalan dengan hasil penelitian Hidayat dan Nugroho (2010) yang menggunakan Theory of Planned Behavior (TPB) untuk menjelaskan perilaku ketidakpatuhan wajib pajak orang pribadi. Hasil penelitian yang sama juga ditemukan oleh Pontoh et al. (2013), yang menyatakan bahwa persepsi Kontrol Komunikasi dan Manajemen Data Nasional (KOMANDAN) Sistem Informasi Keuangan Daerah (SIKD) tidak memiliki pengaruh yang positif dan signifikan terhadap niat menggunakan KOMANDAN SIKD. Namun berdasarkan Theory of Planned Behavior, semakin besar kontrol perilaku persepsian, semakin kuat niat seseorang untuk melakukan perilaku yang sedang dipertimbangkan.

Penjelasan yang dapat diajukan dari hasil penelitian ini, yaitu aparatur pemerintah daerah beranggapan bahwa implementasi PP Nomor 71 Tahun 2010 dianggap belum begitu perlu, karena secara teknis pelaksanaannya belum dilakukan oleh pemerintah daerah. Aparatur pemerintah juga mempercayai bahwa mereka belum mempunyai sumber daya dan faktor-faktor pendukung yang dapat memfasilitasi implementasi PP Nomor 71 Tahun 2010. Dalam Jogiyanto (2008) dijelaskan bahwa kepercayaan-kepercayaan yang paling utama menentukan niat dan tindakan adalah sekumpulan kontrol yang berhubungan dengan kehadiran atau ketidak-hadiran dari sumbersumber daya yang dibutuhkan. Olehnya itu, untuk membangun kepercayaan-kepercayaan kontrol dari aparatur pemerintah daerah, salah satu langkah yang dapat dilakukan, yaitu dengan menyediakan anggaran untuk melakukan pelatihan dan sosialisasi secara bertahap dan berkelanjutan. Melalui kegiatan ini, diharapkan aparatur pemerintah mendapatkan pemahaman yang lebih menyeluruh mengenai PP Nomor 71 Tahun 2010.

Kesiapan organisasi untuk berubah erat kaitannya dengan komitmen (commitment) dan keyakinan-sendiri (self efficacy) dari semua anggota organisasi untuk mengimplementasikan perubahan organisasi. Hasil penelitian ini membuktikan bahwa kesiapan untuk berubah (readiness for change) merupakan 
prediktor terbaik dalam memprediksi niat implementasi Peraturan Pemerintah Nomor 71 Tahun 2010. Kesiapan untuk berubah, menunjukkan harapan dari aparatur pemerintah daerah kota dan kabupaten se Sulawesi Tengah, bahwa perubahan standar akuntansi pemerintahan berbasis akrual melalui implementasi PP Nomor 71 Tahun 2010, dapat membawa perubahan yang lebih baik bagi perencanaan, peningkatan, pengelolaan, dan pengendalian asset, serta penilaian kinerja. Hasil penelitian ini sejalan dengan hasil penelitian yang dilakukan oleh Eby et al. (2010), Nugraheni (2012), dan Kwakh dan Lee (2008).

Kesiapan dari aparatur pemerintah daerah kota dan kabupaten se-Sulawesi untuk melakukan perubahan, salah satunya didukung oleh masa kerja dari aparatur. Data demografi responden menunjukkan $79,49 \%$ responden memiliki masa kerja atau lama menduduki jabatan kurang dari tiga tahun. Hanpachern, Morgan, dan Griego (1998) menyatakan bahwa masa kerja merupakan salah satu prediktor kesiapan untuk berubah, karyawan yang baru bekerja dalam suatu perusahaan memiliki kesiapan untuk berubah yang lebih tinggi dibandingkan karyawan yang telah lama bekerja. Responden pada penelitian ini seluruhnya adalah termasuk dalam tingkat jabatan pimpinan. Dalam hal ini Hanpachern, Morgan, dan Griego (1998) menyatakan bahwa karyawan yang termasuk kedalam tingkat jabatan pimpinan akan lebih siap untuk berubah, karena mereka dibekali terlebih dahulu dengan informasi yang lengkap mengenai pelaksanaan perubahan.

Strategi sosialisasi dan pelatihan mengenai penerapan PP Nomor 71 Tahun 2010, dilakukan oleh pemerintah Kota dan Kabupaten se-Sulawesi Tengah secara berjenjang dari pimpinan level kebijakan sampai dengan pelaksana teknis. Tujuannya adalah untuk meningkatkan skill pelaksana, membangun awareness, dan mengajak keterlibatan semua pihak. Disamping itu, kegiatan ini juga dapat membentuk komitmen dan keyakinan-sendiri (self efficacy) dari aparatur pemerintah daerah. Tingkatan self efficacy yang tinggi akan menimbulkan niat yang lebih kuat untuk mem- bentuk suatu perilaku (Bandura, 1977). Pertimbangan-pertimbangan keyakinan-sendiri diyakini memengaruhi respon-respon emosional dari individual. Individual-individual akan cenderung menyukai dan menikmati perilakuperilaku yang mereka rasakan mereka mampu melakukannya dengan baik. Pernyataan ini didukung oleh hasil penelitian Betz dan Hackett (1981) yang menemukan bahwa persepsi-persepsi keyakinan sendiri secara signifikan berhubungan dengan perasaan atau niat.

\section{SIMPULAN}

Sikap terhadap perilaku dan norma subyektif dari TPB, serta kesiapan untuk berubah merupakan penentu dari niat implementasi peraturan pemerintah nomor 71 Tahun 2010. Aparatur pemerintah daerah memercayai dan berharap bahwa implementasi PP Nomor 71 Tahun 2010 akan membantu aktivitas kerja mereka, dapat memberikan hasil yang positif, dan implementasi tersebut mendapat dukungan dari atasan serta rekan kerja mereka. Dari ketiga variabel penentu niat tersebut, kesiapan untuk berubah merupakan prediktor terbaik dalam memprediksi niat. Hal ini berarti pada dasarnya aparatur pemerintah daerah telah siap menghadapi implementasi PP nomor 71 tahun 2010. Namun masih terdapat kendala yang menghambat kinerja aparatur, yaitu pengetahuan, kemampuan, dan sumber daya dari aparatur. Kendala-kendala ini ditunjukkan oleh variabel kontrol perilaku persepsian yang tidak berpengaruh signifikan terhadap niat implementasi implementasi PP Nomor 71 Tahun 2010. Berdasarkan hasil penelitian yang telah dilakukan, peneliti menyarankan agar peneliti selanjutnya dapat menambahkan lingkup lokasi penelitian agar generalisasi hasil penelitian dapat lebih luas. Metode eksperimen juga dapat diterapkan, agar memberikan gambaran yang semakin utuh dan menyeluruh mengenai faktor-faktor lain yang dapat menjadi prediktor niat. Terakhir, penelitian ini dapat diperluas dengan menambahkan variabel ekspektasi kinerja dan dukungan organisasi, atau dapat juga dengan menggunakan model TPB yang diuraikan. 


\section{DAFTAR REFERENSI}

Ajzen, I.,dan M. Fishbein. 1970. The prediction of behavior from attitudinal and normative variable. Journal of Experimental Social Psychology 6 (4): 466-487.

Ajzen, I. 1991. The theory of planned behavior. Organizational Behavior and Human Decision Processes. 50 (2): $179-211$.

Ajzen, I. 2002. Perceived behavioral control, self-efficacy, locus of control, and theory of planned behavior. Journal of Apllied Social Psychology 32 (4): 665683.

Ajzen, I. 2005. Attitudes, personality, and behavior ( $2^{\text {nd }}$ Edition). England: Open University Press/McGraw- Hill.

Betz. N. E., dan G. Hackett. 1981. The relationship of career-related selfefficacy expectations to perceived career option in college women and men. Journal of Counseling Psychology 28 (5): 399-410.

Bandura, A. 1977. Self-efficacy: Toward a unifying theory of behavioral change. Psychological Review 84 (2): 191-215.

Bidin, Z., F. M. Shamsudin, M. S. Shalihen, dan O. M. Zainudin. 2011. Factors influencing intention to comply with local sale tax in Malaysia. Society of Interdisciplinary Business Research (SIBR) Conference on Interdisciplinary Business Research.

Badan Pemeriksa Keuangan Republik Indonesia (BPK RI) Perwakilan Sulawesi Tengah. 2014. Hasil pemeriksaan atas LKPD TA 2013 tujuh kota dan kabupaten di Sulawesi Tengan mendapat opini WDP. http://www.palu.bpk.go.id/?p=14583 (Däkses 20 Juni 2014).

Eby, L., D. Adams, J. Russel, dan S. Gaby. 2000. Perceptions of organizational readiness for change: Factor related to employees reactions to the imple mentation of team based selling. Human Relations 53 (3): 419-442.

Fishbein, M., dan I. Ajzen, I. 1975. Belief, attitude, intention, and behavior: An introduction to theory and research. MA: Addison-Wesley.

Hartwick, J., dan H. Barki. 1994. Explaning the role of user participation in information system use. Management Science 40 (4): 440-465.

Hanpachern, C., G. A. Morgan, dan O. V. Griego. 1998. An extension of the theory of margin: A framework for assessing readiness for change. Human Resource Development Quarterly 9 (4): 339-350.

Hidayat, W., dan A. A. Nugroho. 2010. Studi empiris theory of planned behavior dan pengaruh kewajiban moral pada perilaku ketidakpatuhan pajak wajib pajak orang pribadi. Jurnal Akuntansi Dan Keuangan 12 (2): 82-93.

Holt, D. T., A. A. Armenakis, H. S. Feild, dan S. G. Harris. 2007. Readiness for organizational change: The systematic development of a scale. The Journal of Applied Behavioral Science 43 (2): 232-255.

Huda, N., N. Rini, Y. Mardoni, dan P. Putra. 2012. The analysis of attitudes, subjective norms, and behavioral control on muzakki's intention to pay zakah. International Journal of Business and Social Science 3 (2): 271-279.

Jogiyanto. 2008. Sistem informasi keperilakuan. Yogyakarta: Penerbit ANDI.

Jogiyanto., dan W. Abdillah. 2009. Konsep dan aplikasi PLS (Partial Least square) untuk penelitian empiris. Yogyakata: BPFE.

Kwahk, K-Y., dan J-N. Lee. 2008. The role of readiness for change in ERP imple mentation and empirica 1 validation. 
Journal Information and Management 45 (7): 474-481.

Mustikasari, E. 2007. Kajian empiris tentang kepatuhan wajib pajak badan di perusahaan industri pengolahan di Surabaya. Simposium Nasional Akuntansi X Makassar.

Nugraheni, A. L. 2012. Pelatihan self efficacy untuk meningkatkan kesiapan pegawai dalam menghadapi perubahan pada karyawan PT. PLN (Persero) PUSDIKLAT. Tesis., Universitas Indonesia.

Ozer, G., dan E. Yilmaz. 2011. Comparison of the theory of reasoned action and the theory of planned behavior: An application on accountans information technology usage. African Journal of Business Management 5 (1): 50-58.

Pangestu, F., dan O. Rusmana. 2012. Analisis faktor-faktor yang berpengaruh terhadap tax compliance penyetoran SPT masa (Survey pada PKP yang terdaftar di KPP Pratama Purwokerto). Simposium Nasional akuntansi $X V$ Banjarmasin.

Pemerintah Republik Indonesia. 2010. Peraturan Pemerintah No. 71 Tahun 2010 Tentang Standar Akuntansi Pemerintahan (Berbasis Akrual).

Pontoh, G. T., M. Mustafa, Haliah, dan Kartini. 2013. Analisis pemanfaatan sistem informasi KOMANDAN SIKD pada provinsi dan kabupaten/kota di Sulawesi. Jurnal BPPK 6 (1).

Sihombing, S. O. 2004. Hubungan sikap dan perilaku memilih satu merek: Komparasi antara theory of planned behavior dan theory of trying. Disertasi., Universitas Gadjah Mada.

Schifter, D.E., and I. Ajzen. 1985. Intention, perceived control, and weight loss: An application of the theory of planned behavior. Journal of Personality and Social Psychology 49 (3): 843-851.

Smart, M. 2012. The application of the theory of planned behaviour and structural equation modelling in tax compliance behaviour: A New Zealand study. Disertasi., University of Canterbury.

Taylor, S., dan P. A. Todd. 1995. Understanding information technology usage: A test of competing models. Informational Systems Research 6 (2): 144-176.

Walinga, J. 2008. Toward a theory of change readiness: The role of appraisal, focus, and perceived control. The Journal of Applied Behavioral Science 44 (3): 315-347.

Weiner, B. J. 2009. A theory of organizational readiness for change, implementation science. Implementation Science 4 (67). 